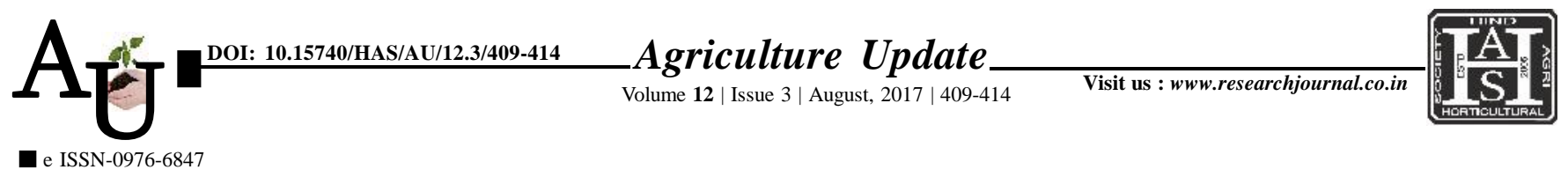

\title{
Research ARticle: Role of women in agriculture as farmer and labour : An empirical evidences of farm women involvement in agriculture operations in Jaipur district of Rajasthan state
}

\author{
a PHOOL CHAND MEENA AND PREM CHAND MEENA
}

Article Chronicle: Received : 25.05.2017;

Revised :

23.06.2017;

Accepted :

06.07.2017

KeY Words:

Farm women,

Agricultural

operations,

Household, Women,

Harvesting

Author for correspondence :

PHOOL CHAND MEENA Department of

Agriculture Economics,

Agriculture University, JODHPUR (RAJASTHAN)

INDIA

Email:bassi_meena@

rediffmail.com

See end of the article for authors' affiliations
SUMMARY : The present paper aimed to investigate the total number of days spent by women in agriculture during a year and time spent for different agricultural operations in both Rabi and Kharif seasons in Jaipur district of Rajasthan State. The study was based on random sampling method for the year 2012-2013. To ascertain the objective primary data were collected by conducting personnel interview method with help of schedules specially developed for the purpose. The study revealed that major proportion (more than $90.00 \%$ ) of the respondents participated in activities like application of fertilizers, manuring, intercultural operations, harvesting, threshing, winnowing, transportation and storage of produce. The findings also reveals in both Rabi and Kharif the maximum percentage time spent (23-26 $\%$ ) was in intercultural operations as a single activity followed by harvesting. Out of all the major activities least time was spent on nursery bed, seed bed preparation and transplanting during both Kharif and Rabi season. Further, the study also indicates that the total number of average hours spent per day was 5.17 in Kharif and 5.47 in Rabi season. However, the total number of hours of work per day varied according to the nature of agricultural activities being performed by them. Hence, the study suggest that despite the fact that though women contribute more in agriculture/farm related activities than men, their involvement in decision making processis extreme disadvantage in terms of rights, pay and participation in local producers organizations. The main cause for this situation is due lack of empowerment which has repeatedly fallout in negative externalities such as poor health and less or no education for women in farm families. Thus, the study suggest that future strategies should framed in such way that women would be actively involved in farm decision process both at the government and household level.

How to cite this article : Meena, Phool Chand and Meena, Prem Chand (2017). Role of women in agriculture as farmer and labour : An empirical evidences of farm women involvement in agriculture operations in Jaipur district of Rajasthan state. Agric. Update, 12(3): 409-414; DOI : 10.15740/HAS/AU/12.3/409-414. 